\title{
BMJ A community cohort study about open childhood social and economic circumstances: racial/ethnic differences and associations with educational attainment and health of older adults
}

\author{
Irene $\mathrm{H}$ Yen, ${ }^{1}$ Steven Gregorich, ${ }^{2}$ Alison K Cohen, ${ }^{3}$ Anita Stewart ${ }^{4}$
}

To cite: Yen IH, Gregorich S, Cohen AK, et al.

A community cohort study about childhood social and economic circumstances: racial/ethnic differences and associations with educational attainment and health of older adults. BMJ Open 2013:3:e002140

doi:10.1136/bmjopen-2012002140

- Prepublication history for this paper are available online. To view these files please visit the journal online (http://dx.doi.org/10.1136/ bmjopen-2012-002140).

Received 28 September 2012 Revised 6 March 2013 Accepted 7 March 2013

This final article is available for use under the terms of the Creative Commons Attribution Non-Commercial 2.0 Licence; see http://bmjopen.bmj.com

For numbered affiliations see end of article.

\section{Correspondence to} Dr Irene $\mathrm{H}$ Yen; irene.yen@ucsf.edu

\section{ABSTRACT}

Objectives: Typical measures of childhood socioeconomic status (SES), such as father's occupation, have limited the ability to elucidate mechanisms by which childhood SES affects adult health. Mechanisms could include schooling experiences or work opportunities. Having previously used qualitative methods for concept development, we developed new retrospective measures of multiple domains of childhood social and economic circumstances in ethnically diverse older adults. We administered the new measures in a large sample and explored their association with adult SES.

Design: We used a cross-sectional survey design with a community sample.

Setting: The San Francisco Bay Area in California. Participants: 400 community-dwelling adults from diverse racial/ethnic backgrounds (Whites, African Americans, Latinos and Asians/Pacific Islanders) aged 55 and older (mean $=67$ years); $61 \%$ were women.

Primary and secondary outcome measures: We measured attitudes towards schooling, extracurricular activities and adult encouragement and discouragement during the childhood/teen years. Bivariate analysis tested racial/ethnic differences on the various measures. Multivariate regression models estimated the extent to which retrospective circumstances were independently associated with adult educational attainment and adult health.

Results: Most of the childhood circumstances measures differed across racial/ethnic groups. In general, Whites reported more positive circumstances than non-Whites. Family financial circumstances, respondent's perception of schooling as a means to get ahead, high school extracurricular activities, summer travel and summer reading were each statistically significantly associated with adult SES. Family composition, age began work, high school extracurricular activities, attitudes towards schooling and adult discouragement were associated with adult health.

\section{ARTICLE SUMMARY}

Article focus

- Introduces new retrospective measures of childhood social and economic circumstances, different from parents' socioeconomic status (SES); eg, school quality, extracurricular activities and adult support.

- Shows racial/ethnic differences of childhood circumstances for a community sample of older adults.

- Investigates if childhood circumstances measures are associated with adult SES.

- Investigates if childhood circumstances are associated with adult health.

Key messages

- Childhood circumstances measures have good reliability and variability.

- Most childhood circumstances differed across racial/ethnic groups.

- Childhood circumstances are associated with adult SES.

- Childhood circumstances (family composition, age began working and school experiences) are associated with adult health, even after taking into consideration a traditional measure of childhood socioeconomic circumstances and adult socioeconomic circumstances.

Strengths and limitations of this study

- Introduces new retrospective measures that broaden the domains of childhood circumstances with potential relevance to health.

- Uses the measures to describe circumstances in a racially/ethnically mixed community sample of older adults.

\section{INTRODUCTION}

Adult socioeconomic status (SES) is a key social factor associated with a wide variety of health behaviours and health outcomes. Adult SES is often measured by educational 
attainment or income. Educational attainment and income are correlated, but education is a process that begins in childhood. More recently, measures of wealth or assets have also been used in addition to educational attainment or income to more comprehensively describe SES. ${ }^{12}$

In order to understand why SES is so important for health, it is helpful to look at the trajectory of SES over a person's lifetime, beginning with childhood. In fact, childhood SES has emerged as an important social factor for health in childhood and adulthood. ${ }^{3}$

Childhood SES is associated with adult health behaviors ${ }^{4}$ and specific health conditions in adult populations, ${ }^{5-9}$ and its influence continues into middle and older ages. ${ }^{10-12}$ Disadvantageous circumstances during childhood also appear to influence health conditions for adults over age $60^{13-15}$ and risk for premature mortality. ${ }^{10} 11 \quad 16-22$

However, there are several limitations with this body of research regarding identifying how and to what extent childhood socioeconomic circumstances affect the health of older adults. First, only a few studies extend into older ages so there is a gap in understanding how childhood SES may influence health of older adults. Most studies have focused on middle-aged adults or the general adult population. ${ }^{10} 17 \quad 192122$ If people with lower SES in childhood die younger, perhaps the effect of childhood SES is diminished for people who live into older ages. If there are effects that extend to older ages, it could argue even more strongly for childhood interventions. Understanding the duration of influence of childhood SES on health, that is, whether the influence continues into older ages, has both scientific and health policy value, especially as the world's population ages.

Second, with the exception of a number of important studies using the US Health and Retirement Survey, ${ }^{23-25}$ most studies with regard to the effects of childhood SES mentioned above were cohort studies conducted on large population samples in Europe. ${ }^{10} 1617$ 20-22 Since social and economic circumstances have strong ties to culture and social policy (eg, school experiences and summer break), the location of the research is relevant. Also, European middle and older age populations are more ethnically homogeneous than the US population, so European study populations preclude further investigation into the possibly different roles that a variety of childhood circumstances may play depending on race/ ethnicity. In order to pursue this research in the USA with the racial/ethnic heterogeneity, it is most practical to use existing cohorts and add retrospective measures. We need appropriate survey tools to assess childhood circumstances of older adults using retrospective designs.

Third, with a few exceptions, previous studies measure childhood SES in terms of parental SES, such as father's occupation, mother's employment status, father's educational attainment or some combination of parents' educational attainment. ${ }^{11} 142026-31$ Some studies have used other variables that describe social or economic circumstances such as family size and configuration, family financial status, father's unemployment, housing characteristics (eg, number of rooms), father's absence and marital status of the mother at the time of child's birth. ${ }^{3} 121823$ In order to fully understand how parents' SES eventually affects adult health, though we must also measure the experiences and circumstances of individuals throughout their childhood. Figure 1 illustrates the intervening variables that potentially mediate the observed associations between parents' SES and adult health, such as school quality or supportive adults that are amenable to early-life interventions and can have effects across the lifespan.

To advance this field of study, we need retrospective measures that more comprehensively assess early-life socioeconomic circumstances that may affect adult health. Retrospective measures allow for more costeffective research that can estimate provisional relationships between a broad array of childhood circumstances and adult health. These relationships can then be confirmed with prospective cohort studies. We first developed a comprehensive, multidimensional conceptual framework of childhood circumstances and experiences that ethnically diverse older adults believe affect their health using qualitative interview methods. ${ }^{32}$ Seven key domains were identified: home and family circumstances, neighbourhood, work and money, potential for advancement through schooling, school quality and content, influence and support of adults and leisure activities.

The purpose of this paper was to describe new retrospectively assessed measures of SES-related childhood circumstances based on our framework, explore whether these childhood circumstances differed across racial/ ethnic groups, and investigate if the measures are associated with older adults' SES and health. As much of the previous literature has used parental SES to measure childhood SES, we also were interested to learn if the new measures were simply proxies for parental SES or captured additional dimensions of childhood beyond what is conferred through parents' SES. Therefore, our research questions are (1) Which childhood social and economic circumstances ('childhood circumstances')

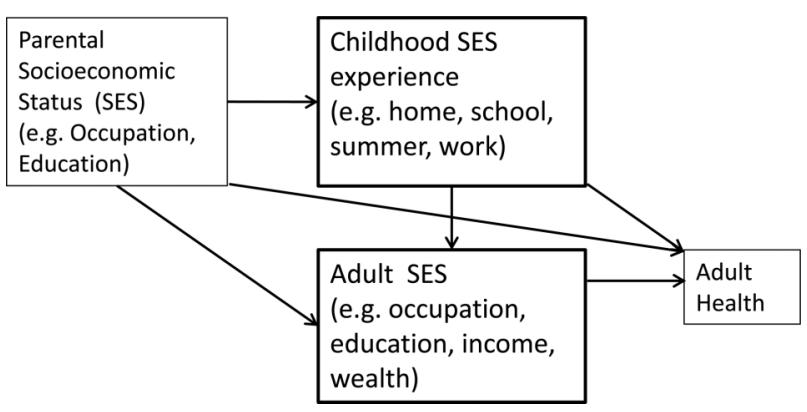

Figure 1 Diagram demonstrating the hypothesised relationship between socioeconomic status (SES) and health at different points in the lifecourse. 
are associated with adult SES (measured with adult educational attainment)? (2) Which childhood circumstances are associated with older adult health? (3) Are childhood circumstances still associated with older adult health, after controlling for father's educational attainment, the current body of literature's most common way to measure childhood SES? (4) Are childhood circumstances associated with older adult health after accounting for adult SES? And finally, (5) are childhood circumstances associated with older adult health after controlling for both father's SES and respondent's SES?

\section{METHODS}

\section{Development of measures}

We first created 53-survey items that reflected all of the domains (3-8 items per domain) in the conceptual framework, based on the qualitative data. ${ }^{32}$ Two phases of pretesting were conducted with racially/ethnically diverse older adults. First, we pilot tested these items with 19 older adults to determine if wording was clear, if response categories were adequate and if we were missing any other circumstances. Participants understood the items could recall their childhoods such that they could answer the items, and found that the response categories reflected their circumstances. We revised a few items based on their input. For example, an item about extracurricular activities was revised to include church or community organisations that organised youth activities. We subsequently conducted more in-depth cognitive interview pretesting with 32 older adults. After completing the survey, respondents were asked questions about how they interpreted the wording of items and whether the response categories provided were satisfactory and reflected their circumstances adequately. In general, participants interpreted the items as intended. Based on their feedback, we revised a few items to increase clarity. For example, we added a clarifying phrase to two items about summer leisure activities and to an item about working regularly.

\section{Survey field test}

The 53-item Childhood social and economic circumstances survey was administered to a new sample of ethnically diverse older adults. We also included one measure of adult SES (adult education) and one traditional measure of childhood SES (father's educational attainment).

Respondents were recruited between May 2007 and November 2008 in the San Francisco Bay Area through senior centres, posted flyers in public places, senior health fairs and referrals from respondents. Eligibility criteria for survey respondents included ages 55 and older; born in the USA or emigrated before the age of 16 and self-identified as White, African American, Latino or Asian. Eligible participants in another study who indicated a willingness to be contacted for future studies were also contacted and invited to participate. ${ }^{33}$ The goal was to survey approximately 400 people, equally distributed among the four racial/ethnic groups (White, Black, Latino/a and Asian/Pacific Islander) and approximately $60 \%$ women (to reflect their distribution in the population).

Surveys were administered to respondents on the telephone or in person. Respondents received a $\$ 10$ gift card for their participation. All study procedures were approved by the University of California, San Francisco Committee, on Human Research.

\section{Methods of analysis}

To create scales from the survey items, we grouped items by domains and determined appropriate ways to combine items (eg, mean of the responses to two items about perceived school quality-one for middle school and one for high school; sum of periods of deprivation-ever a time when family focus on surviving and ever a time when family did not have enough to eat). In some cases, factor analysis was used to determine which items within a set of items clustered together and could be combined in a scale. For example, there is a question about summer activities, which asks about socialising with friends, watching television, staying at home doing chores, working, playing sports or reading. Factor analysis revealed that reading did not cluster with the other items, so it was treated as a single-item scale. Descriptive analysis of the individual measures and scales were performed including mean, $\mathrm{SD}$ and observed range. To explore racial/ethnic group differences in the mean scores of the final scales, bivariate analyses included $\chi^{2}$ and $\mathrm{F}$ tests.

\section{Childhood social and economic circumstances-scale construction}

Scales were created within the seven domains. The scales ranged from single items to multi-item. For example, in the domain of 'Home and family circumstances', two items ('Was there ever a time when your family focused on surviving or just 'getting by'? and 'Was there ever a time when your family did not have enough to eat?') formed the scale 'deprivation'. Table 1 describes the items and scales and indicates the observed range. Internal-consistency reliability is shown for multi-item scales. Briefly, here is a description of each of the domains and the scales corresponding to each.

Home and family circumstances: housing tenure, moving, primary adults who raised the person (eg, 1 parent, 2 parents and grandparents) and family economic conditions.

Neighbourhood: the type of neighbourhood (eg, middle class and working class) and the proportion of neighbours who were the same race/ethnicity as the respondent.

Work and money: age when the respondent started working regularly for pay and how much work for pay during summer vacations.

Potential for advancement through schooling: parents' views about schooling for their children and the 
Table 1 Description of Childhood Social and Economic Circumstances Domains and Scales

\begin{tabular}{|c|c|c|c|c|c|c|c|}
\hline Domain/scale & Definition & $\begin{array}{l}\text { Number of } \\
\text { items }\end{array}$ & Mean (SD) & $\begin{array}{l}\text { Possible } \\
\text { range }\end{array}$ & $\begin{array}{l}\text { Observed } \\
\text { range }\end{array}$ & $\alpha$ & $\begin{array}{l}\text { Meaning of high } \\
\text { score }\end{array}$ \\
\hline \multicolumn{8}{|l|}{ Home and family circumstances } \\
\hline $\begin{array}{l}\text { Number of times renting } \\
\text { during } 4 \text { periods of } \\
\text { childhood }(0-4)\end{array}$ & $\begin{array}{l}\text { Rented during } 4 \text { periods of childhood: } 0-5,6-9 \text {, } \\
10-14,15-18\end{array}$ & 4 & $2.07(1.62)$ & $0-4$ & $0-4$ & - & $\begin{array}{l}\text { More periods of } \\
\text { renting }\end{array}$ \\
\hline $\begin{array}{l}\text { Number of times moved } \\
\text { (categories) }\end{array}$ & $0,1,2,3,4+$ & 1 & $3.31(1.48)$ & $1-5$ & $1-5$ & - & More moves \\
\hline Raised by 2 parents $(1 / 0)$ & $\begin{array}{l}\text { Raised by both parents vs raised by one parent, a } \\
\text { grandparent, a parent and a step parent, or some } \\
\text { other combination of adults }\end{array}$ & 1 & 0.67 & $0-1$ & $0-1$ & - & Raised by 2 parents \\
\hline Deprivation & $\begin{array}{l}\text { Periods when their family was just surviving or when } \\
\text { there was not enough food to eat or both }\end{array}$ & 2 & $0.79(0.77)$ & $0-2$ & $0-2$ & - & $\begin{array}{l}\text { More periods of } \\
\text { disadvantage }\end{array}$ \\
\hline Family financial status & $\begin{array}{l}\text { Rating of family's financial status as } 1=\text { pretty well } \\
\text { off, } 2=\text { about average, } 3=\text { poor }\end{array}$ & 1 & $2.28(0.61)$ & $1-3$ & $1-3$ & - & Poorer status \\
\hline \multicolumn{8}{|l|}{ Neighbourhood } \\
\hline Neighbourhood type & $\begin{array}{l}\text { 1=upper middle class } \\
2=\text { middle } \\
3=\text { lower middle class } \\
4=\text { working class }\end{array}$ & 1 & $3.02(1.00)$ & $1-4$ & $1-4$ & - & Lower income type \\
\hline $\begin{array}{l}\text { Neighbours who are same } \\
\text { ethnicity }\end{array}$ & $\begin{array}{l}\text { How many neighbours were the same race/ethnicity } \\
\text { as themselves with } 1=\text { none, } 2=a \text { few, } 3=\text { about half } \\
\text { and } 4=\text { all or most }\end{array}$ & 2 & $3.32(0.97)$ & $1-4$ & $1-4$ & - & $\begin{array}{l}\text { Higher proportion } \\
\text { same ethnicity }\end{array}$ \\
\hline \multicolumn{8}{|l|}{ Work and money } \\
\hline $\begin{array}{l}\text { Age began working } \\
\text { regularly }\end{array}$ & & 1 & 16.11(3.19) & & $7-35$ & - & Older age \\
\hline Summer work for pay & $\begin{array}{l}\text { Extent of working for pay during middle- and high } \\
\text { school summers }\end{array}$ & 2 & $2.49(1.10)$ & $1-4$ & $1-4$ & 0.63 & $\begin{array}{l}\text { More work during } \\
\text { summer }\end{array}$ \\
\hline \multicolumn{8}{|l|}{$\begin{array}{l}\text { Potential for advancement } \\
\text { through schooling }\end{array}$} \\
\hline $\begin{array}{l}\text { Parent attitude towards } \\
\text { education }\end{array}$ & $\begin{array}{l}\text { Extent to which parents paid attention to grades, } \\
\text { stressed importance of education }\end{array}$ & 2 & $3.16(0.98)$ & $1-4$ & $1-4$ & 0.82 & $\begin{array}{l}\text { More support for } \\
\text { schooling }\end{array}$ \\
\hline $\begin{array}{l}\text { Perceived importance of } \\
\text { education }\end{array}$ & $\begin{array}{l}\text { Respondent's sense that schooling is important to } \\
\text { get a good job }\end{array}$ & 1 & $3.44(0.92)$ & $1-4$ & $1-4$ & - & More important \\
\hline \multicolumn{8}{|l|}{ School quality and content } \\
\hline Perceived school quality & $\begin{array}{l}\text { Rating of quality of middle and high school } \\
\text { education }\end{array}$ & 2 & $2.99(0.77)$ & $1-4$ & $1-4$ & 0.76 & $\begin{array}{l}\text { Higher perceived } \\
\text { quality }\end{array}$ \\
\hline $\begin{array}{l}\text { Extracurricular activities- } \\
\text { high school }\end{array}$ & $\begin{array}{l}\text { Number of years on organised sports, school clubs, } \\
\text { school organisations }\end{array}$ & 3 & $2.85(2.75)$ & $0-9$ & $0-9$ & 0.59 & More extracurricular \\
\hline $\begin{array}{l}\text { Music extracurricular } \\
\text { activities-high school }\end{array}$ & $\begin{array}{l}\text { Number of years in band/choir or taking music } \\
\text { lessons }\end{array}$ & 2 & $1.28(1.98)$ & $0-6$ & $0-6$ & 0.71 & $\begin{array}{l}\text { More music } \\
\text { activities }\end{array}$ \\
\hline
\end{tabular}




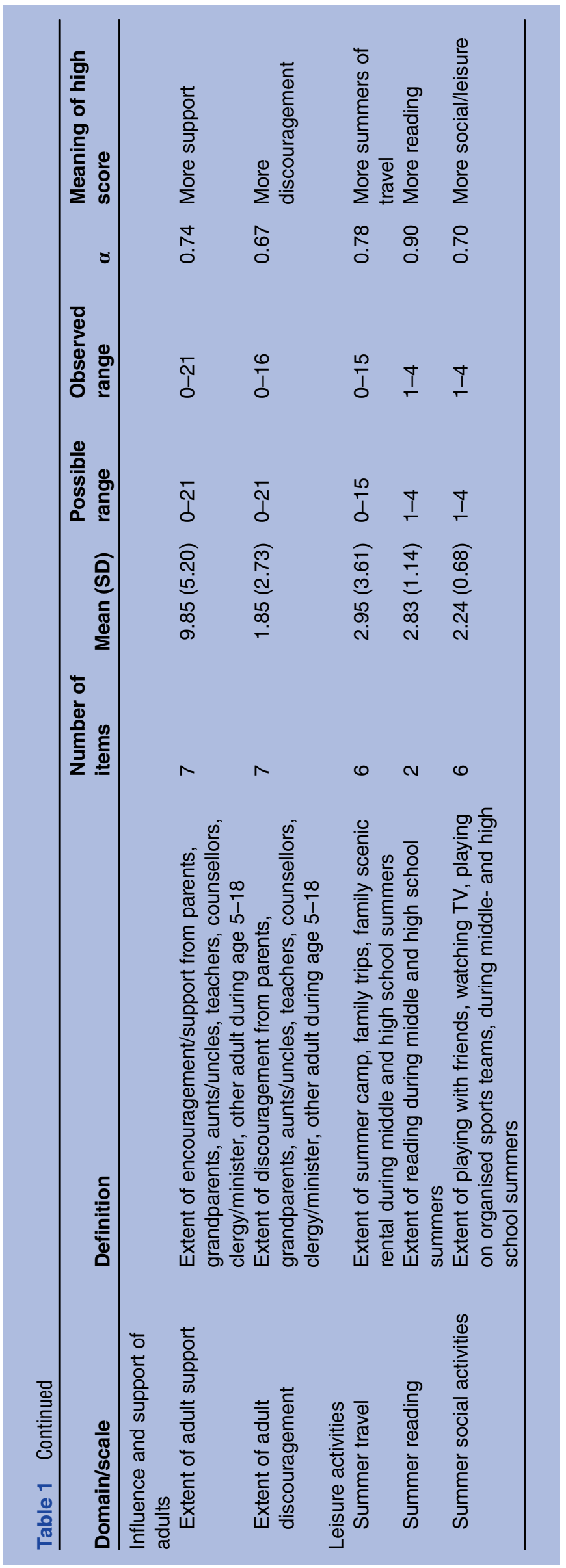

respondent's own attitude towards schooling as a means for getting ahead.

School quality and content: perceived quality of schooling, the quality of schooling (whether school offered college preparatory classes) and participation in extracurricular activities in high school.

Influence and support of adults: support or discouragement from parents, grandparents, aunts or uncles, teachers, school counsellors, clergy or friends of parents. Respondents were asked to indicate how much support or discouragement, if any, they received while growing up from seven different adults.

Leisure activities: organised and unorganised activities respondents did for fun or recreation, including summertime activities.

In most instances, the observed range of the item or scale was the same as the possible range, indicating good variability. The items that composed multi-item scales had high Cronbach's $\alpha$ values (ranging from 0.63 to 0.90) indicating moderate-to-high internal consistency.

\section{Adult SES measure}

Adult SES was measured using by adult educational attainment in years, which ranged from 0 to 19 .

\section{Health status measures}

Three measures of health were included: (1) perceived health status; (2) SF-36 physical functioning measure; ${ }^{34}{ }^{35}$ and self-reports of chronic conditions ('Has a doctor ever told you that you have osteoporosis, diabetes, arthritis, chronic bronchitis or emphysema, asthma, hypertension, heart disease, a stroke or cancer?'). Perceived health was modelled as a continuous variable (range: $1=$ poor to $5=$ excellent). SF-36 was also modelled as a continuous variable (possible range 0-100).

\section{Multivariate analysis}

Bivariate regression models estimated the association of each childhood circumstance scale with adult educational attainment. A multivariate linear regression model with backward elimination estimated conditional associations between childhood circumstances and adult educational attainment (SES); explanatory variables with $p$ values $\leq 0.20$ were retained; all models forced inclusion of demographic variables age, sex and race/ethnicity (Model 1). Model 2 added the father's education (this study's measure of parental SES, the traditional measure of childhood SES). Next, multivariate linear regression models with backward elimination estimated conditional associations between childhood circumstances and each health outcome. Explanatory variables with $\mathrm{p}$ values $\leq 0.20$ were retained; all models forced inclusion of demographic variables age, sex and race/ethnicity (Model 1). Model 2 added the father's education. Model 3 added the current education (our measure for adult SES) to Model 1. Model 4 added the father's education and current education to Model 1. 


\section{RESULTS}

Demographic and health characteristics of the survey sample are shown in table 2. By design, the sample included more women $(61 \%)$ and roughly one-quarter each of White, Latino, African American and Asian respondents. Recruiting Latinos was more difficult because of the inclusion criteria that respondents be born in the USA or have emigrated before the age of 16. Respondents ranged in age from 55 to 93 (mean=67.3) and had a broad range of educational attainment levels. One-third (34\%) of their fathers completed grade school only, one-quarter $(27 \%)$ had a high school education and one-fifth (19\%) did not know what level of education their father had attained.

Notable statistics described in table 3 indicate that (1) about two-thirds reported that they had been raised by both parents and (2) respondents reported receiving far more support from adults than discouragementgiven a possible range of $0-21$, the mean was nearly 10 for support and only 2 for discouragement.

Most of the childhood circumstances scales differed by racial/ethnic group. In general, White respondents reported more positive circumstances. Whites were less likely to live in a rented home than people in the other racial/ethnic groups. Whites and Asians were more

\begin{tabular}{|c|c|}
\hline Demographic characteristics & $\begin{array}{l}\text { Survey respondents } \\
(n=400)\end{array}$ \\
\hline \multicolumn{2}{|l|}{ Sex } \\
\hline Male & $155(39 \%)$ \\
\hline Female & $245(61 \%)$ \\
\hline Age in years & Mean $=67.3(55-93)$ \\
\hline \multicolumn{2}{|l|}{ Race/ethnicity } \\
\hline White/other & $104(26 \%)$ \\
\hline Latino & $93(23 \%)$ \\
\hline African American & $101(25 \%)$ \\
\hline Asian or Pacific Islander (API) & $102(26 \%)$ \\
\hline \multicolumn{2}{|l|}{ Education } \\
\hline$\leq$ High school & $32(8 \%)$ \\
\hline High school graduate & $87(22 \%)$ \\
\hline Some college & $138(35 \%)$ \\
\hline College graduate & $67(17 \%)$ \\
\hline Graduate degree & $76(19 \%)$ \\
\hline \multicolumn{2}{|l|}{ Father's education } \\
\hline No formal education & $19(6 \%)$ \\
\hline Grade school & $110(34 \%)$ \\
\hline Some high school & $30(9 \%)$ \\
\hline $\begin{array}{l}\text { High school equivalency or } \\
\text { diploma }\end{array}$ & $109(27 \%)$ \\
\hline $\begin{array}{l}\text { Associate's or Bachelor's } \\
\text { degree }\end{array}$ & $36(9 \%)$ \\
\hline Graduate degree & $22(6 \%)$ \\
\hline Unknown & $77(19 \%)$ \\
\hline Health status measures & Mean (SD), range \\
\hline Self-rated health & $3.2(1.1), 1-5$ \\
\hline Physical functioning & 73.7 (29.2), 0-100 \\
\hline
\end{tabular}

likely to be raised by two parents; Blacks were least likely to be raised by two parents. Whites were more likely to say their family's financial status was 'pretty well off' and less likely to say they were 'poor' than people in the other racial/ethnic groups. Latinos and Asians were more likely to say that their families were 'poor'. Whites were less likely to report deprivation during their childhood than people in the other racial/ethnic groups; Latinos were more likely to report both types of deprivation than the other groups. Whites and Blacks were more likely to grow up in neighbourhoods where most of the neighbours were the same race/ethnicity as themselves. Whites reported higher perceived middle and high school quality than the other racial/ethnic groups. Whites and Blacks reported more adult support than the overall average; Asians reported less.

The associations between measures of childhood circumstances and adult education are shown in table 4 . Unadjusted models showed that the frequency of renting versus owning a home during four periods of childhood was negatively associated with adult educational attainment. Also, moving more often during childhood was associated with lower educational attainment. Being raised by two parents, as compared with any other household arrangement, was positively associated with educational attainment. All school variables were positively associated with adult SES: parents' stressing the importance of schooling, individual's own perception of schooling as a means to get ahead, perceived quality of schooling, participation in high school extracurricular activities and high school music-related extracurricular activities. Summer travel and reading were also positively associated with adult SES.

Multivariate regression modelling (Model 1) identified family financial circumstances, parents' stressing the importance of schooling, respondent's perception of schooling as a way to get ahead, extracurricular activities during high school (marginally), summer travel and summer reading as uniquely and significantly associated with adult educational attainment. After taking into consideration the father's educational attainment (the traditional measure of childhood SES, Model 2), family financial circumstances, respondent's perception of schooling as a way to get ahead and summer reading remained associated with adult SES.

The childhood circumstances associated with adult self-rated health in bivariate models were raised by two parents, age began working regularly for pay, respondent's perception of schooling as a means to get ahead, perceived school quality, high school extracurricular activities, high school music extracurricular activities and summer reading (table 5). From the backwards elimination process (Model 1), raised by two parents, age started to work, respondent's perception of schooling as a means to get ahead, and high school extracurricular activities were the childhood circumstances significantly associated with self-rated health. Taking into consideration the father's education (Model 2), being raised by 
Table 3 Childhood circumstances by race/ethnicity

\begin{tabular}{|c|c|c|c|c|c|c|}
\hline & $\begin{array}{l}\text { Total } \\
\text { sample } \\
\text { n (\%) }\end{array}$ & $\begin{array}{l}\text { White } \\
\text { n (\%) }\end{array}$ & $\begin{array}{l}\text { African } \\
\text { American } \\
\text { n (\%) }\end{array}$ & $\begin{array}{l}\text { Latino } \\
\text { n (\%) }\end{array}$ & $\begin{array}{l}\text { API } \\
\text { n (\%) }\end{array}$ & $\chi^{2} / F$ test ( $p$ value) \\
\hline \multicolumn{7}{|l|}{ Demographics } \\
\hline Father's education, N (\%) & & & & & & $\chi^{2}=35.62(0.002)$ \\
\hline No education & $19(5)$ & $1(1)$ & $3(3)$ & $10(11)$ & $5(5)$ & \\
\hline Grade school & $110(28)$ & $23(22)$ & $24(24)$ & 36 (39) & $27(26)$ & \\
\hline Some high & $30(8)$ & $11(11)$ & $4(4)$ & $7(8)$ & $8(8)$ & \\
\hline High school & $109(27)$ & $30(29)$ & $34(34)$ & 18 (19) & $27(26)$ & \\
\hline College+ & $58(15)$ & $24(23)$ & $11(11)$ & $9(10)$ & $14(14)$ & \\
\hline Missing & 74 (19) & $15(14)$ & $25(25)$ & $13(14)$ & $21(21)$ & \\
\hline Adult education, N (\%) & & & & & & $\chi^{2}=61.86(<0.0001)$ \\
\hline$<$ High school & $32(\%)$ & $3(3)$ & $11(11)$ & $17(8)$ & $1(1)$ & \\
\hline High school graduate & 87 (22) & $23(22)$ & $33(33)$ & $15(16)$ & $16(16)$ & \\
\hline Some college & $138(35)$ & $32(31)$ & $42(42)$ & $33(36)$ & $31(31)$ & \\
\hline College graduate & $67(17)$ & $18(17)$ & $12(12)$ & $12(13)$ & $25(25)$ & \\
\hline Postgraduate & 74 (19) & $28(27)$ & $3(3)$ & $15(16)$ & $28(28)$ & \\
\hline \multicolumn{7}{|l|}{ Childhood circumstances } \\
\hline \multicolumn{7}{|l|}{ Home and family circumstances } \\
\hline Rent (\# periods renting), $\mathrm{N} \%$ ) & & & & & & $\chi^{2}=22.62(0.03)$ \\
\hline 0 & $111(28)$ & $43(43)$ & $28(28)$ & $22(24)$ & $18(18)$ & \\
\hline 1 & $44(11)$ & $9(9)$ & $13(13)$ & $9(10)$ & $13(13)$ & \\
\hline 2 & 69 (18) & $13(13)$ & $15(15)$ & $22(24)$ & $19(19)$ & \\
\hline 3 & $45(11)$ & $9(9)$ & $11(11)$ & $14(15)$ & $11(11)$ & \\
\hline 4 & $125(32)$ & $26(26)$ & $34(34)$ & $25(27)$ & $40(40)$ & \\
\hline Moves (number of time), $\mathrm{N}(\%)$ & & & & & & $\chi^{2}=12.87(0.38)$ \\
\hline 0 & $64(16)$ & $24(23)$ & $18(18)$ & $11(12)$ & $11(11)$ & \\
\hline 1 & $70(18)$ & $16(15)$ & $17(17)$ & $14(15)$ & $23(23)$ & \\
\hline 2 & 75 (19) & $19(18)$ & $19(19)$ & $22(24)$ & $15(15)$ & \\
\hline 3 & $61(15)$ & $11(11)$ & $16(16)$ & $15(16)$ & $19(19)$ & \\
\hline $4+$ & $130(33)$ & $34(33)$ & $31(31)$ & $31(33)$ & $34(33)$ & \\
\hline Two parents-yes, N (\%) & $268(67)$ & $78(75)$ & $50(50)$ & $62(67)$ & $78(76)$ & $\chi^{2}=21.13^{\star * *}$ \\
\hline Deprivation & & & & & & $\chi^{2}=17.72(0.007)$ \\
\hline 0 & $170(43)$ & $58(56)$ & $45(45)$ & $32(34)$ & $35(34)$ & \\
\hline 1 & $143(36)$ & $31(30)$ & $36(36)$ & $32(34)$ & $44(43)$ & \\
\hline 2 & $85(21)$ & $14(14)$ & $19(19)$ & $29(31)$ & $23(23)$ & \\
\hline Family financial status, $\mathrm{N}(\%)$ & & & & & & $\chi^{2}=13.60(0.03)$ \\
\hline Pretty well off & $33(8)$ & $14(14)$ & $3(3)$ & $9(10)$ & $7(7)$ & \\
\hline About average & $222(56)$ & $61(59)$ & $63(63)$ & $46(49)$ & $52(51)$ & \\
\hline Poor & $143(36)$ & $28(27)$ & $34(34)$ & $38(41)$ & $43(42)$ & \\
\hline \multicolumn{7}{|l|}{ Neighbourhood } \\
\hline Neighbourhood type, N (\%) & & & & & & $\chi^{2}=27.34(0.001)$ \\
\hline Upper middle class & $29(7)$ & $14(13)$ & $3(3)$ & $7(8)$ & $5(5)$ & \\
\hline Middle & $119(30)$ & $41(39)$ & $22(22)$ & $32(34)$ & $24(24)$ & \\
\hline Lower middle class & $78(20)$ & $14(13)$ & $21(21)$ & $15(16)$ & $28(28)$ & \\
\hline Working class & $173(43)$ & $35(34)$ & $55(54)$ & $39(42)$ & $44(44)$ & \\
\hline $\begin{array}{l}\text { Proportion neighbourhood same } \\
\text { race/ethnicity }\end{array}$ & & & & & & $\chi^{2}=67.10(<0.0001)$ \\
\hline None or a few & $96(24)$ & $5(5)$ & $12(12)$ & $39(42)$ & $40(39)$ & \\
\hline Some & $56(14)$ & $11(11)$ & $19(19)$ & $16(17)$ & $10(10)$ & \\
\hline Most & $248(62)$ & $88(85)$ & $70(69)$ & $38(41)$ & $52(51)$ & \\
\hline \multicolumn{7}{|l|}{ Work and money } \\
\hline Age started work, N (\%) & & & & & & $\chi^{2}=13.17(0.04)$ \\
\hline$<16$ & $159(40)$ & $37(36)$ & $39(39)$ & $43(46)$ & $40(40)$ & \\
\hline $16-18$ & $174(44)$ & $55(53)$ & $47(47)$ & $37(40)$ & $35(35)$ & \\
\hline $19+$ & $66(17)$ & 12 (12) & $15(15)$ & $13(14)$ & $26(26)$ & \\
\hline Summer work for pay & 2.49 & 2.46 & 2.62 & 2.41 & 2.55 & $F=0.65(0.58)$ \\
\hline
\end{tabular}


Table 3 Continued

\begin{tabular}{|c|c|c|c|c|c|c|}
\hline & $\begin{array}{l}\text { Total } \\
\text { sample } \\
\text { n (\%) }\end{array}$ & $\begin{array}{l}\text { White } \\
\text { n (\%) }\end{array}$ & $\begin{array}{l}\text { African } \\
\text { American } \\
\text { n (\%) }\end{array}$ & $\begin{array}{l}\text { Latino } \\
\text { n (\%) }\end{array}$ & $\begin{array}{l}\text { API } \\
\text { n (\%) }\end{array}$ & $\chi^{2} / F$ test ( $p$ value) \\
\hline Parent attitude towards education & 3.16 & 3.14 & 3.48 & 3.01 & 3.00 & $\begin{array}{l}\text { White-Black (0.01) } \\
\text { Black-Latino } \\
(0.0009) \\
\text { Black-API }(0.0004)\end{array}$ \\
\hline Not at all & $30(8)$ & $6(6)$ & $2(2)$ & $11(12)$ & $11(11)$ & \\
\hline A little & $30(8)$ & $7(7)$ & $12(12)$ & $6(6)$ & $5(5)$ & \\
\hline Somewhat & $73(18)$ & $26(25)$ & $17(17)$ & $16(17)$ & $14(14)$ & \\
\hline A lot & $267(67)$ & $65(63)$ & $70(69)$ & $60(65)$ & $72(71)$ & \\
\hline Extracurricular high school, mean & 2.85 & 3.03 & 2.92 & 3.06 & 2.74 & $\mathrm{~F}=0.28(0.84)$ \\
\hline $\begin{array}{l}\text { Music extracurricular high school, } \\
\text { mean }\end{array}$ & 1.28 & 1.78 & 1.44 & 0.88 & 1.09 & $F=3.82(0.01)$ \\
\hline \multicolumn{7}{|l|}{ Influence and support of adults } \\
\hline Extent of adult support & 9.85 & 10.11 & 12.56 & 9.06 & 7.60 & $\mathrm{~F}=18.50^{\star \star \star}$ \\
\hline Extent of adult discouragement & 1.85 & 1.88 & 1.57 & 2.37 & 1.61 & Black-Latino (0.04) \\
\hline \multicolumn{7}{|l|}{ Leisure activities } \\
\hline Summer travel & 2.95 & 4.33 & 2.15 & 3.14 & 2.48 & $\begin{array}{l}\text { White-Black } \\
(<0.0001) \\
\text { White-Latino (0.02) } \\
\text { White-API (0.0002) }\end{array}$ \\
\hline Summer reading & 2.83 & 2.99 & 2.89 & 2.67 & 2.91 & $F=1.3(0.26)$ \\
\hline
\end{tabular}

two parents became marginally statistically significant, but the other childhood circumstances remained associated with self-rated health. (We also note that for Models 1 and 2, age began working was associated with self-rated health in the opposite way than we would expect such that the older the age began working was associated with poorer self-rated health.) After adjusting for adult SES (Model 3), age began working and high school extracurricular activities were the two childhood circumstances that remained associated with adult selfrated health. Taking into consideration both father's education and adult SES (Model 4), only age began working was associated with self-rated health.

The childhood circumstances associated with physical functioning in bivariate models were raised by two parents, age began working regularly for pay, parents' emphasis on schooling, respondent's perception of schooling, high school extracurricular activities and adult discouragement. From the backwards elimination process (Model 1), raised by two parents, age started working regularly for pay, respondent's perception of schooling as a means to get ahead and adult discouragement were the childhood circumstances that are significantly associated with physical functioning. Taking into consideration the father's education (Model 2), with the exception of raised by two parents, the other childhood circumstances remain associated with physical functioning. After adjusting for adult SES (Model 3), with the exception of raised by two parents, the other childhood circumstances remain associated with physical functioning. Taking into consideration both father's education and adult SES (Model 4), age began working, respondent's perception of schooling as a means to get ahead and adult discouragement remain associated with physical functioning.

\section{DISCUSSION}

In a multiethnic sample of older adults, we developed about 20 scales within seven domains previously identified to be important childhood circumstances. Then, in an initial application of the new items in a larger ethnically diverse sample, we surveyed 400 older adults using the new scales. These questions assessed childhood 
Table 4 Childhood circumstances and adult education: $\beta$ coefficients from regression models $(n=381)$

\begin{tabular}{|c|c|c|c|}
\hline & Unadjusted & Model 1 & $\begin{array}{l}\text { Model2=Model 1+ } \\
\text { father's education }\end{array}$ \\
\hline \multicolumn{4}{|l|}{ Demographics } \\
\hline \multicolumn{4}{|l|}{ Variable } \\
\hline Age & $-0.026(0.09)$ & $-0.032(0.0004)$ & $-0.032(0.01)$ \\
\hline Sex (male) & 0.10 & 0.26 & $0.30(0.17)$ \\
\hline \multicolumn{4}{|l|}{ Race/ethnicity } \\
\hline African American & $-1.54^{\star \star \star}$ & $-1.54^{\star \star \star}$ & $-1.35^{\star \star \star}$ \\
\hline Asian & 0.42 & $0.59(0.05)$ & $0.71(0.02)$ \\
\hline Latino & $-1.25(0.0009)$ & $-0.40(0.20)$ & -0.30 \\
\hline White & REF & REF & REF \\
\hline \multicolumn{4}{|l|}{ Father's education } \\
\hline No education & $-3.04^{\star \star \star}$ & - & $-0.82(0.18)$ \\
\hline Grade school & $-1.34(0.001)$ & - & $-0.69(0.05)$ \\
\hline Some high & $-1.32(0.02)$ & - & $-0.79(0.10)$ \\
\hline High school & $-0.95(0.02)$ & - & $-0.60(0.08)$ \\
\hline Missing & $-2.95^{\star \star \star}$ & - & $-1.72^{\star \star \star *}$ \\
\hline College+ & REF & & REF \\
\hline \multicolumn{4}{|l|}{ Childhood circumstances } \\
\hline \multicolumn{4}{|l|}{ Home and family circumstances } \\
\hline Rent & $-0.25(0.0004)$ & $-0.11(0.13)$ & $-0.12(0.11)$ \\
\hline Moves & $-0.21(0.02)$ & $-0.13(0.10)$ & $-0.14(0.08)$ \\
\hline Two parents & $0.83(0.004)$ & $0.37(0.12)$ & 0.19 \\
\hline Family financial & $-0.34(0.14)$ & $0.50(0.01)$ & $0.53(0.008)$ \\
\hline Deprivation & $-0.29(0.10)$ & - & - \\
\hline \multicolumn{4}{|l|}{ Neighbourhood } \\
\hline Neighbourhood type & $-0.24(0.07)$ & - & - \\
\hline Proportion neighbours same ethnicity & -0.15 & - & - \\
\hline \multicolumn{4}{|l|}{ Work and money } \\
\hline Age started work & 0.24 & - & - \\
\hline Working & -0.13 & - & - \\
\hline \multicolumn{4}{|l|}{ Potential for advancement through schooling } \\
\hline Parent attitude towards education & $0.65^{\star \star \star}$ & $0.25(0.05)$ & 0.17 \\
\hline Perceived importance of education & $0.89^{\star \star *}$ & $0.27(0.04)$ & $0.31(0.02)$ \\
\hline \multicolumn{4}{|l|}{ School quality and content } \\
\hline Perceived school quality & $0.51(0.0007)$ & - & - \\
\hline Extracurricular activities high school & $0.17^{\star * *}$ & $0.077(0.06)$ & $0.059(0.15)$ \\
\hline Music extracurricular high school & $0.17^{\star \star *}$ & - & - \\
\hline \multicolumn{4}{|l|}{ Influence and support of adults } \\
\hline Extent of adult support & $0.064(0.01)$ & - & - \\
\hline Extent of adult discouragement & 0.049 & - & - \\
\hline \multicolumn{4}{|l|}{ Leisure activities } \\
\hline Summer travel & $0.15^{\star \star \star}$ & $0.07(0.03)$ & $0.063(0.06)$ \\
\hline Summer reading & $0.45^{\star \star \star}$ & $0.29(0.005)$ & $0.26(0.0009)$ \\
\hline Summer social activities & $0.30(0.08)$ & - & $-0.27(0.18)$ \\
\hline $\mathrm{R}^{2}$ & & 0.27 & 0.31 \\
\hline
\end{tabular}

circumstances retrospectively including family financial circumstances, perception of schooling, parent's attitude towards schooling and summer activities. There were prominent racial/ethnic differences across different types of childhood circumstances. African Americans had poorer circumstances in almost every domain, except for parental attitude towards school-where they indicated more support for schooling as a way to get ahead than the people in all other racial/ethnic groups-and extent of adult support. Asians and Latinos also fared more poorly than the Whites on several measures, such as periods of renting, moves, deprivation, parent attitude towards school, perceived school quality, extent of adult support and summer travel.

In bivariate analyses, measures within home and family, potential for advancement through schooling, 
Table 5 Childhood circumstances and adult health: multivariate linear regression models of self-rated health and physical functioning

\begin{tabular}{|c|c|c|c|c|c|c|c|c|c|c|}
\hline & \multicolumn{5}{|c|}{ Self-rated health $(n=384)$} & \multicolumn{5}{|c|}{ Physical functioning $(n=388)$} \\
\hline & Unadjusted & Model 1 & Model 2 & Model 3 & Model 4 & Unadjusted & Model 1 & Model 2 & Model 3 & Model 4 \\
\hline \multicolumn{11}{|l|}{ Demographics } \\
\hline Variable & $B$ ( $p$ value $)$ & & & & & & & & & \\
\hline Age & 0.0037 & 0.00078 & 0.0036 & 0.0052 & 0.0064 & $-0.25(0.12)$ & $-0.49(0.009)$ & $-0.45(0.02)$ & $-0.42(0.02)$ & $-0.42(0.03)$ \\
\hline Sex (male) & -0.083 & -0.11 & -0.10 & -0.14 & -0.13 & 2.34 & 2.91 & 3.27 & 2.53 & 2.86 \\
\hline \multicolumn{11}{|l|}{ Race/ethnicity } \\
\hline African American & $-0.31(0.05)$ & $-0.21(0.18)$ & $-0.18(0.18)$ & -0.71 & -0.68 & -0.25 & 0.43 & 1.68 & $5.64(0.18)$ & $6.22(0.14)$ \\
\hline Asian & $0.24(0.12)$ & $0.34(0.03)$ & $0.36(0.02)$ & $0.30(0.05)$ & $-0.31(0.04)$ & $12.79(0.002)$ & $11.51(0.004)$ & $12.17(0.002)$ & $-10.34(0.008)$ & $10.80(0.006)$ \\
\hline Latino & -0.12 & -0.039 & -0.012 & 0.010 & 0.029 & 2.89 & 1.12 & 1.31 & 4.27 & 4.03 \\
\hline White & REF & REF & REF & REF & REF & REF & REF & REF & REF & REF \\
\hline \multicolumn{11}{|l|}{ Father's education } \\
\hline No education & -0.30 & - & -0.16 & - & -0.11 & -2.19 & - & -6.28 & - & -3.40 \\
\hline Grade school & $-0.43(0.02)$ & - & $-0.35(0.05)$ & - & $-0.31(0.09)$ & 3.00 & - & 2.60 & - & 4.22 \\
\hline Some high & $-0.55(0.03)$ & - & $-0.48(0.05)$ & - & $-0.41(0.09)$ & 3.25 & - & 5.52 & - & $8.42(0.17)$ \\
\hline High school & $-0.36(0.04)$ & - & $-0.29(0.11)$ & - & $-0.24(0.18)$ & -0.82 & - & -0.34 & - & 1.00 \\
\hline Missing & $-0.66(0.0007)$ & - & $-0.41(0.05)$ & - & -0.26 & $-11.37(0.03)$ & - & $-7.62(0.15)$ & - & -4.20 \\
\hline College+ & REF & - & REF & - & REF & REF & - & REF & - & REF \\
\hline \multicolumn{11}{|l|}{ Adult education } \\
\hline$<$ high school & $-1.04^{\star *}$ & - & - & $-0.73(0.01)$ & $-0.71(0.02)$ & $-28.68^{\star \star \star}$ & - & - & $-30.23^{\star \star \star}$ & $-28.91(0.0001)$ \\
\hline High school graduate & $-0.75^{\star \star \star}$ & - & - & $-0.52(0.005)$ & $-0.47(0.01)$ & $14.47(0.001)$ & - & - & $-10.64(0.02)$ & $-9.29(0.05)$ \\
\hline Some college & $-0.48(0.002)$ & - & - & $-0.29(0.07)$ & $-0.26(0.12)$ & $-14.68(0.0003)$ & - & - & $-12.33(0.003)$ & $-11.98(0.004)$ \\
\hline College graduate & -0.35 & - & - & -0.17 & -0.15 & -4.19 & - & - & -0.91 & 0.01 \\
\hline Postgraduate & REF & - & - & REF & REF & REF & - & - & REF & REF \\
\hline \multicolumn{11}{|l|}{$\begin{array}{l}\text { Childhood circumstance } \\
\text { Economic and family } \\
\text { circumstances }\end{array}$} \\
\hline Rent & -0.029 & $-0.046(0.19)$ & -0.042 & -0.036 & -0.032 & 0.067 & - & - & - & - \\
\hline Moves & -0.010 & - & - & - & - & 0.22 & - & - & - & - \\
\hline Two parents & $0.43(0.0003)$ & $0.25(0.04)$ & $0.22(0.08)$ & $0.21(0.09)$ & $0.20(0.11)$ & $9.97(0.001)$ & $6.48(0.04)$ & $5.34(0.10)$ & $5.27(0.09)$ & $4.52(0.15)$ \\
\hline Family financial & -0.11 & - & - & - & - & -0.11 & - & - & - & - \\
\hline Deprivation & -0.077 & - & - & - & - & -1.69 & - & - & - & - \\
\hline \multicolumn{11}{|l|}{ Neighbourhood } \\
\hline Neigh type & -0.054 & - & - & - & - & -0.16 & - & - & - & - \\
\hline $\begin{array}{l}\text { Proportion neigh } \\
\text { same race/ethnicity }\end{array}$ & -0.023 & - & - & - & - & 0.018 & - & - & - & - \\
\hline \multicolumn{11}{|l|}{ Work and money } \\
\hline Age started work & $-0.26(0.0009)$ & $-0.31^{* * *}$ & $-0.31^{* * *}$ & $-0.31^{* * *}$ & $-0.31^{\star * *}$ & $-5.15(0.01)$ & $-4.89(0.01)$ & $-4.55(0.02)$ & $-5.32(0.007)$ & $-5.04(0.01)$ \\
\hline Working & $0.087(0.09)$ & - & - & - & - & $1.73(0.19)$ & - & - & - & - \\
\hline \multicolumn{11}{|l|}{ Schooling } \\
\hline $\begin{array}{l}\text { Parent attitude towards } \\
\text { education }\end{array}$ & 0.070 & - & - & - & - & $3.11(0.04)$ & - & - & - & - \\
\hline $\begin{array}{l}\text { Perception importance of } \\
\text { education }\end{array}$ & $0.18(0.002)$ & $0.15(0.02)$ & $0.16(0.02)$ & $0.12(0.06)$ & $0.13(0.05)$ & $5.43(0.0006)$ & $6.48(0.0001)$ & $6.24(0.0003)$ & $4.70(0.006)$ & $4.48(0.009)$ \\
\hline \multirow[t]{2}{*}{ Perceived school quality } & $0.24(0.001)$ & - & - & - & - & $3.67(0.06)$ & - & - & - & - \\
\hline & $0.075(0.0002)$ & $0.051(0.01)$ & $0.045(0.03)$ & $0.040(0.05)$ & $0.036(0.08)$ & $1.11(0.04)$ & $1.01(0.07)$ & $0.96(0.08)$ & $0.72(0.19)$ & $0.76(0.17)$ \\
\hline
\end{tabular}




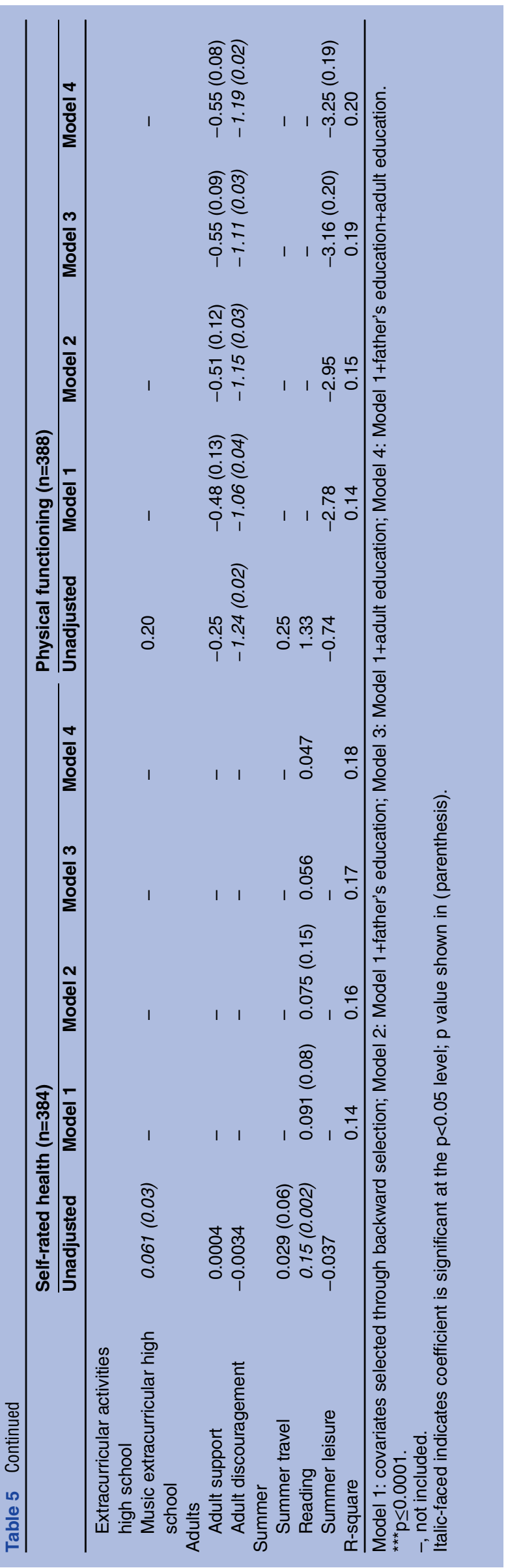

school quality and content, influence and support of adults and leisure activities each were associated with adult educational attainment after adjusting for age, sex and race/ethnicity. Several scales were associated with adult education, including family financial situation, parent attitude towards education, perceived importance of education, summer travel and summer reading. Importantly, other measures which are often seen to be markers of SES, for example, housing tenure, economic deprivation and age started work, were not associated with adult educational attainment, suggesting that these measures may reflect other dimensions of social and economic circumstances. These findings are generally in agreement with sociology and education research that have used data collected during childhood and adolescence directly. ${ }^{36-40}$ Results thus support the validity of these retrospective reports by older adults, suggesting that they provide useful insights into socioeconomic experiences in childhood and adolescence.

Multivariate analysis suggests that specific childhood experiences related to family composition, working and school experiences are associated with adult health outcomes even after taking into consideration the father's SES (a traditional measure of childhood SES) and adult SES.

There are a number of study limitations. The survey sample was a purposive sample, so not representative of people age 55 and older. Indeed the educational attainment data suggest that these people were better educated than the general population, with one-third of the sample having at least a college degree. As with any study that relies on self-reporting, the childhood circumstances items are subject to the accurate recall of the respondent. Finally, the survey sample is older adults and thus the results could be affected by survivorship selection bias. This could lead to an underestimate in the effects of childhood circumstances if those with poorer circumstances did not survive.

In the USA, the ability to measure childhood experiences of a racially/ethnically diverse sample of older adults could also allow for investigating the underpinnings of socioeconomic and racial/ethnic disparities in health status. With expanded measures, it would be possible to describe and distinguish in more detail the childhood circumstances of people from different racial/ethnic backgrounds. Social science studies have reported that African Americans and Latinos have differential educational opportunities on average, including variations in school resources and school climate. ${ }^{41} 42$ Urban school districts with higher proportions of minority students often have fewer dollars to spend per pupil than suburban, primarily white school districts. ${ }^{43}$ In addition, even among those with the same educational attainment, such as a college degree, racial/ethnic minorities earn lower wages compared with Whites. ${ }^{44} 45$

Since these are retrospective measures, the next steps are to test people's recall of these circumstances by including the most important measures in a future wave of a longitudinal cohort study in which similar measures 
were collected during childhood and adolescence. Eventually, it would be optimal to be able to create a single score summarising each of the seven domains. These data with a purposive sample may not be best suited to create more broadly generalisable summary measures, but are an important first step. Our findings suggest that retrospective self-reports of childhood and adolescent social and economic experiences are a promising approach to examine the nuances of social determinants of health across the lifecourse.

\section{Author affiliations}

${ }^{1}$ Department of Medicine, University of California, San Francisco, California, USA

${ }^{2}$ Department of Medicine, University of California, San Francisco, California, USA

${ }^{3}$ Division of Epidemiology, School of Public Health, University of California, Berkeley, California, USA

${ }^{4}$ Institute for Health and Aging, School of Nursing, University of California, San Francisco, California, USA

Acknowledgements We thank the survey participants, Nancy Adler, Jochebed Catungal, Paulina Flint de Castro and David Burian.

Contributors IHY conceived and supervised the study, conducted the analyses and led the writing. SG advised on the statistical methods and contributed to the writing. AKC assisted with the literature review and writing. AS contributed to the development of the measures, interpretation of the results and manuscript preparation. All authors read and approved the final manuscript.

Funding This project was supported by the University of California, San Francisco (UCSF) Center for Aging in Diverse Communities pilot investigator grants (P30AG015272), UCSF Health Disparities Working Group Seed Grants, UCSF REAC Junior Faculty Research Grant, and UCSF Academic Senate Individual Investigator Award.

\section{Competing interests None.}

Patient consent Obtained.

Ethics approval University of California, San Francisco Committee on Human Research.

Provenance and peer review Not commissioned; externally peer reviewed.

Data sharing statement Survey data could be shared with interested researchers by contacting Irene Yen, corresponding author.

\section{REFERENCES}

1. Meer J, Miller DL, Rosen HS. Exploring the health-wealth nexus. $J$ Health Econ 2003;22:713-30.

2. Perel $P$, Langenberg $C$, Ferrie $J$, et al. Household wealth and the metabolic syndrome in the Whitehall II study. Diabetes Care 2006;29:2694-700.

3. Galobardes B, Smith GD, Lynch JW. Systematic review of the influence of childhood socioeconomic circumstances on risk for cardiovascular disease in adulthood. Ann Epidemiol 2006;16:91-104.

4. Lawlor DA, Batty GD, Morton SM, et al. Childhood socioeconomic position, educational attainment, and adult cardiovascular risk factors: the Aberdeen children of the 1950s cohort study. Am J Public Health 2005;95:1245-51.

5. Gliksman MD, Kawachi I, Hunter D, et al. Childhood socioeconomic status and risk of cardiovascular disease in middle aged US women: a prospective study. J Epidemiol Community Health 1995;49:10-15.

6. Kuh D, Hardy R, Langenberg $C$, et al. Mortality in adults aged 26-54 years related to socioeconomic conditions in childhood and adulthood: post war birth cohort study. BMJ 2002;325:1076-80.

7. Kittleson MM, Meoni LA, Wang NY, et al. Association of childhood socioeconomic status with subsequent coronary heart disease in physicians. Arch Intern Med 2006;166:2356-61.
8. Wannamethee SG, Whincup PH, Shaper G, et al. Influence of fathers' social class on cardiovascular disease in middle-aged men. Lancet 1996;348:1259-63.

9. Singh-Manoux A, Ferrie JE, Chandola T, et al. Socioeconomic trajectories across the life course and health outcomes in midlife: evidence for the accumulation hypothesis? Int J Epidemiol 2004;33:1072-9.

10. Osler M, Andersen AM, Due P, et al. Socioeconomic position in early life, birth weight, childhood cognitive function, and adult mortality. A longitudinal study of Danish men born in 1953. J Epidemiol Community Health 2003;57:681-6.

11. Beebe-Dimmer J, Lynch JW, Turrell G, et al. Childhood and adult socioeconomic conditions and 31-year mortality risk in women. $\mathrm{Am} \mathrm{J}$ Epidemiol 2004;159:481-90.

12. Luo Y, Waite LJ. The impact of childhood and adult SES on physical, mental, and cognitive well-being in later life. J Gerontol $B$ Psychol Sci Soc Sci 2005;60:S93-101.

13. Lynch JW, Kaplan GA, Shema SJ. Cumulative impact of sustained economic hardship on physical, cognitive, psychological, and social functioning. N Engl J Med 1997;337:1889-95.

14. Turrell G, Lynch JW, Kaplan GA, et al. Socioeconomic position across the lifecourse and cognitive function in late middle age. J Gerontol B Psychol Sci Soc Sci 2002;57:S43-51.

15. O'Rand AM, Hamil-Luker J. Processes of cumulative adversity: childhood disadvantage and increased risk of heart attack across the life course. J Gerontol B Psychol Sci Soc Sci 2005;60 (Spec No 2): S117-24.

16. Frankel S, Smith GD, Gunnell D. Childhood socioeconomic position and adult cardiovascular mortality: the Boyd Orr Cohort. Am J Epidemiol 1999;150:1081-4.

17. Davey Smith G, McCarron P, Okasha M, et al. Social circumstances in childhood and cardiovascular disease mortality: prospective observational study of Glasgow University students. J Epidemiol Community Health 2001;55:340-1.

18. Hayward MD, Gorman BK. The long arm of childhood: the influence of early-life social conditions on men's mortality. Demography 2004;41:87-107.

19. Claussen B, Smith G Davey, Thelle D. Impact of childhood and adulthood socioeconomic position on cause specific mortality: the Oslo Mortality Study. J Epidemiol Community Health 2003;57:40-5.

20. Smith G Davey, Hart C, Blane D, et al. Adverse socioeconomic conditions in childhood and cause specific adult mortality: prospective observational study. BMJ 1998;316:1631-5.

21. Naess O, Claussen B, Davey Smith G. Relative impact of childhood and adulthood socioeconomic conditions on cause specific mortality in men. J Epidemiol Community Health 2004;58:597-8.

22. Power C, Hypponen E, Davey Smith G. Socioeconomic position in childhood and early adult life and risk of mortality: a prospective study of the mothers of the 1958 British birth cohort. Am J Public Health 2005;95:1396-402.

23. Haas S. Trajectories of functional health: the 'long arm' of childhood health and socioeconomic factors. Soc Sci Med 2008;66:849-61.

24. Haas S, Rohlfsen L. Life course determinants of racial and ethnic disparities in functional health trajectories. Soc Sci Med 2010;70:240-50.

25. Haas SA, Krueger PM, Rohlfsen L. Race/ethnic and nativity disparities in later life physical performance: the role of health and socioeconomic status over the life course. J Gerontol B Psychol Sci Soc Sci 2012;67:238-48.

26. Lawlor DA, Ebrahim S, Smith G Davey. Socioeconomic position in childhood and adulthood and insulin resistance: cross sectional survey using data from British women's heart and health study. BMJ 2002;325:805.

27. Pollitt RA, Kaufman JS, Rose KM, et al. Cumulative life course and adult socioeconomic status and markers of inflammation in adulthood. J Epidemiol Community Health 2008;62:484-91.

28. Chapman BP, Fiscella K, Duberstein P, et al. Can the influence of childhood socioeconomic status on men's and women's adult body mass be explained by adult socioeconomic status or personality? Findings from a national sample. Health Psychol 2009;28:419-27.

29. Chichlowska KL, Rose KM, Diez-Roux AV, et al. Life course socioeconomic conditions and metabolic syndrome in adults: the Atherosclerosis Risk in Communities (ARIC) Study. Ann Epidemiol 2009;19:875-83.

30. Cleland VJ, Ball K, Magnussen C, et al. Socioeconomic position and the tracking of physical activity and cardiorespiratory fitness from childhood to adulthood. Am J Epidemiol 2009;170:1069-77.

31. Salonen MK, Kajantie E, Osmond C, et al. Role of socioeconomic indicators on development of obesity from a life course perspective. $J$ Environ Public Health 2009;2009:625168. 
32. Yen IH, Stewart AL, Scherzer T, et al. Older adults' perspectives on key domains of childhood social and economic experiences and opportunities: a first step to creating a multidimensional measure. Epidemiol Perspect Innov 2007:4:14.

33. Kaplan CP, Haas JS, Perez-Stable EJ, et al. Breast cancer risk reduction options: awareness, discussion, and use among women from four ethnic groups. Cancer Epidemiol Biomarkers Prev 2006;15:162-6.

34. Haley SM, McHorney CA, Ware JE Jr. Evaluation of the MOS SF-36 physical functioning scale (PF-10): I. Unidimensionality and reproducibility of the Rasch item scale. J Clin Epidemiol 1994;47:671-84.

35. McHorney CA, Haley SM, Ware JE Jr. Evaluation of the MOS SF-36 Physical Functioning Scale (PF-10): II. Comparison of relative precision using Likert and Rasch scoring methods. J Clin Epidemiol 1997;50:451-61.

36. Wilson KJ, Portes A. The educational attainment process: results from a national sample. Am J Sociol 1975;81:343-63.

37. Melby JN, Conger RD, Fang SA, et al. Adolescent family experiences and educational attainment during early adulthood. Dev Psychol 2008:44:1519-36.

38. Spera C, Wentzel KR, Matto HC. Parental aspirations for their children's educational attainment: relations to ethnicity, parental education, children's academic performance, and parental perceptions of school climate. $J$ Youth Adolesc 2009;38: 1140-52.

39. Johnson W, Deary IJ, Silventoinen K, et al. Family background buys an education in Minnesota but not in Sweden. Psychol Sci 2010;21:1266-73.

40. Ganzach Y. Parents' education, cognitive ability, educational expectations and educational attainment: interactive effects. $\mathrm{Br} \mathrm{J}$ Educ Psychol 2000;70(Pt 3):419-41.

41. Bankston C, Caldas SJ. Majority African American schools and social injustice: the influence of defactor segregation on academic achievement. Soc Forces 1996;75:535-55

42. Roscigno VJ. Race and the reproduction of educational disadvantage. Soc Forces 1998:76:1033-60.

43. Ladson-Billings $\mathrm{G}$. From the achievement Gap to the education debt: understanding achievement in U.S. schools. Educ Res 2006;35:3-12.

44. Neal $D$. The measured Black-White wage gap among women is too small. J Political Economy 2004;112:S1-28.

45. Black D, Haviland A, Sanders S, et al. Why do minority men earn less? A study of wage differentials among the highly educated. Rev Econ Stat 2006;88:300-13. 